\title{
The Mukibat system, a high-yielding method of cassava production in Indonesia
}

\author{
G. H. de Bruijn ${ }^{1}$ and T. S. Dharmaputra
}

Faculty of Agriculture, Brawijaya University, Malang, East-Java, Indonesia

Accepted: 19 February 1974

\section{Summary}

Grafting or budding of Manihot glaziovii onto a stock of $M$. esculenta enormously increases production of tuberous roots. This growing system, introduced by a Javanese farmer, Mukibat, outyields ordinary cassava by more than $100 \%$. On average from data in the literature, yields are about 96 tonnes per ha per year.

A description is given of the practice of this system, concerning preparation of plant material, planting method, planting time, intercropping, manuring, plant care, growing period, yield and root quality. Practical significance, potential production and physiological basis of the system are discussed.

\section{Introduction}

In Indonesia the experiments of a farmer, Mukibat, led to the development of a cassava growing system with which very high yields of tuberous roots are obtained. The system is based on grafting or budding of Manihot giaziovii onto a stock of $M$. esculenta. M. glaziovii is a perennial that is often planted in Indonesia as an ornamental cr shade tree. It does not produce any tuberous roots itself.

This 'Mukibat system', named after its inventor, was developed in 1952 in East-Java, in the village of Ngadiloyo (Fig. 1) in the Kediri regency (Koesmadi, 1958), and it is steadily expanding in East-Java and other parts of Indonesia. Spreading is supported by the Agricultural Extension Service. In many places the system is known and put into practice now. In some advanced villages the new system even has superseded the conventional cassava growing system almost completely. In those places $M$. esculenta is now mainly grown to produce stock material (Purwohadi Wijoyo, 1973; Subur Djatiwalujo, 1973). As far as the authors know, hitherto the use of the Mukibat system is still limited to Indonesia.

Up till now no systematic scientific research on the agronomy and economic feasibility of the Mukibat system has been carried out. Some experiments have been done by the Agricultural Extension Service and by research institutes. Publications are scarce and only written in Indonesian. Many trials, often very inventive, have been made by farmers, both with and without co-operation of the Agricultural Extension Service.

Experiments up till now have led to a number of opposing opinions about the

\footnotetext{
1 On assignment from the Department of Tropical Crops, Agricultural University, Wageningen,
} the Netherlands. 


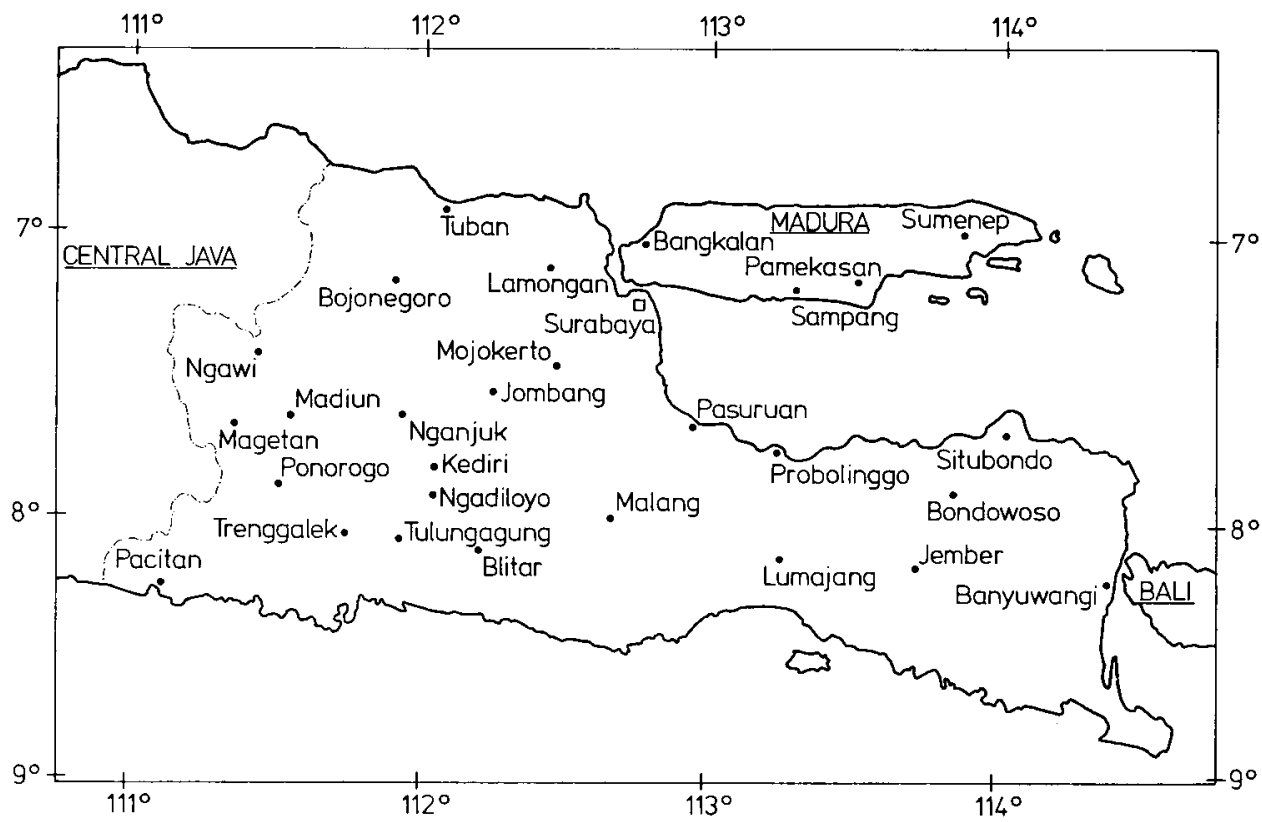

Fig. 1. Sketch map of East-Java.

agronomy of the system, but no disagreement exists on the point of productivity. It is generally admitted that the Mukibat system is greatly outyielding the usual system.

In this paper the authors present information about the new system, based on Indonesian literature data, including reports of a field survey conducted in the main cassava producing areas of East-Java by the Faculty of Agriculture of the Brawijaya University, and on personal observation during field trips.

This Faculty started a research project on the Mukibat system at the end of 1973. The program is carried out in the framework of the cassava research network built up and supported by the International Development Research Centre in Canada. Results of this research will soon be available.

The important consequences which spreading of the Mukibat system might have for cassava production in the world surely justify this early publication.

\section{Practice of the Mukibat system}

\subsection{Preparation of the planting material}

All cassava varieties can be used for the Mukibat system. As yet little is known about specific suitability of varieties for the system. Generally the farmers use local varieties with a good taste and good cooking quality.

Planting material is mostly prepared by grafting, sometimes by budding. 
Grafting. As a rule the splice grafting system is used and executed as follows. On a piece of stem of $M$. esculenta, length $20-30 \mathrm{~cm}$, diameter $2-4 \mathrm{~cm}$, serving as a stock a scion of $M$. glaziovii is grafted, length $10-15 \mathrm{~cm}$, with at least 3 buds and of exactly the same diameter as the stock. Stems serving for stocks should be sufficiently woody, and can be used up till one month after being cut from the mother plant, on condition that they are kept under shade.

Stems used for scion material are generally younger than those used for stock material, and should be used within 10 days after cutting from the mother plant. Some farmers assume that the best results are obtained with scions cut from the mother plant 5 to 10 days beforehand.

Generally the scion material is taken from original $M$. glaziovii plants. Farmers assume that if the scions are taken from $M$. glaziovii stems which already have been growing on a $M$. esculenta stock, the yield of the grafted plants will be less.

After having been cut slantingly, scion and stock are connected with a piece of binding material. Farmers often use banana leaf stalk fibres for this purpose. To facilitate the grafting work a thin piece of bamboo is put in the pith of both scion and stock.

After grafting the cuttings are put under shade at a distance of about $10 \mathrm{~cm}$ and watered daily (Fig. 2). After about 8 days sprouts start to grow. Sprouts from the stock are removed. When the sprouts on the scions are about $2 \mathrm{~cm}$ long the grafted cuttings can be planted in the field or, if this is not yet ready, the shed is removed and transplanting is done later on. According to farmers' experience, a better result is obtained when the grafted cuttings are kept upside down on a dry shady place during five days, after which they are put in the soil in normal position.

If grafting is done in a proper way, up till $90 \%$ of the cuttings will succeed. Some varieties, however, give a lower result. Grafting during the rainy season is said to be less successful than in the dry season; the percentage of success may drop to $50 \%$ or less.

With this type of grafting one person can make about 200 graftings per day.

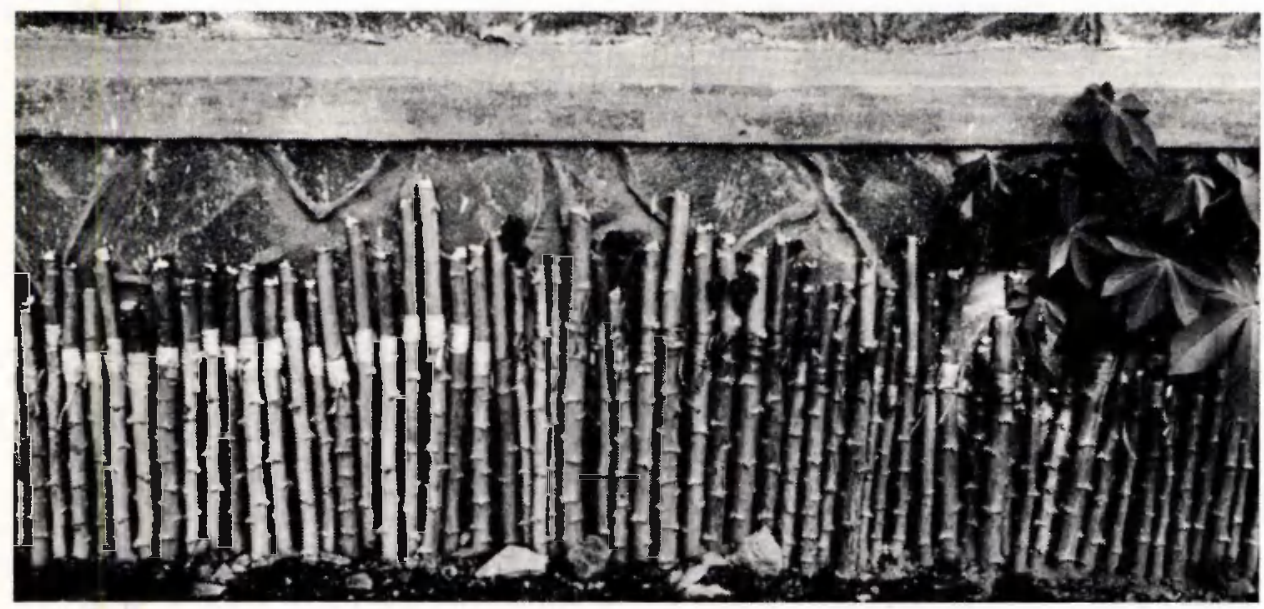

Fig. 2. Grafted cuttings, kept under shade until planting. 

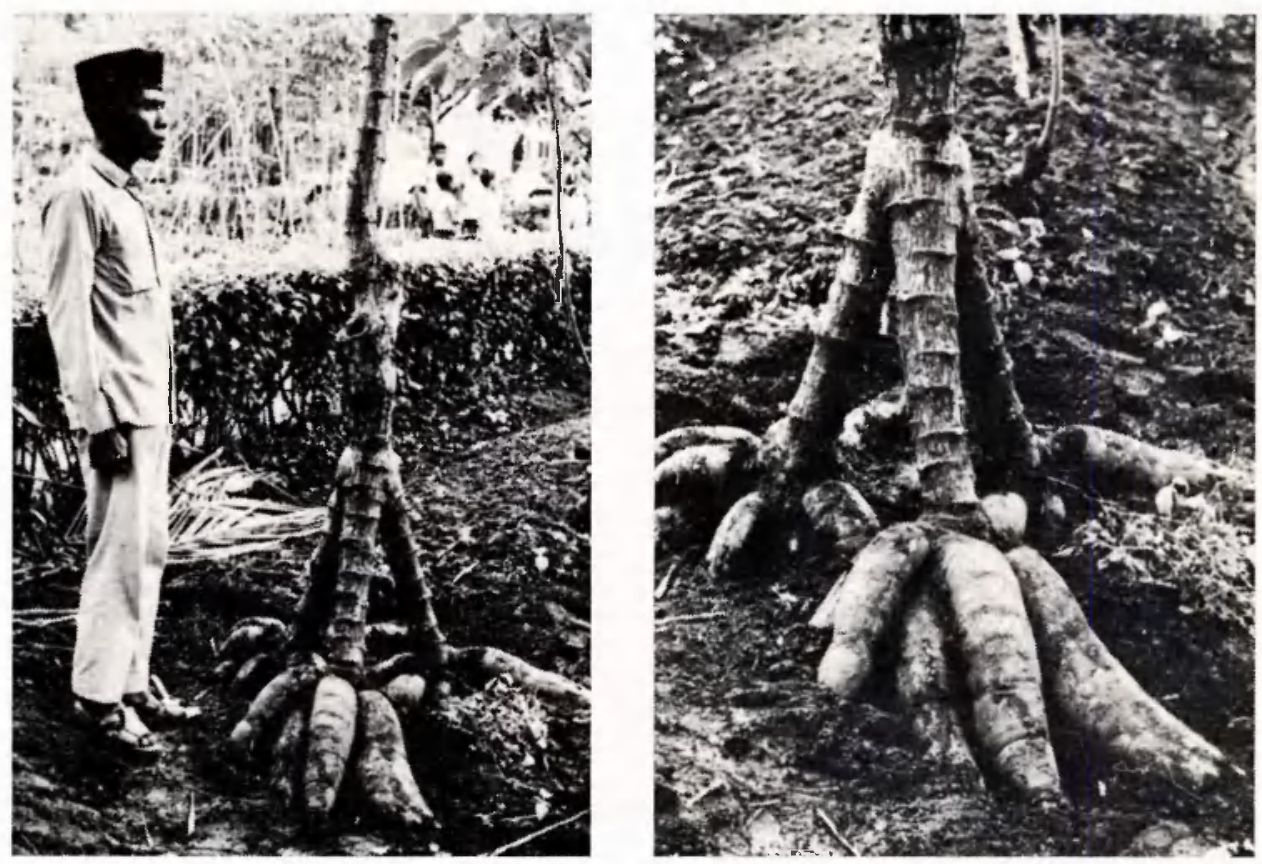

Fig. 3. 'Satrawi' modification of the Mukibat system. Twelve-month old plant. Yield: $104 \mathrm{~kg}$ of tuberous roots (Anon. 1973). Courtesy: Dinas Pertanian Rakyat, Kabupaten Malang.

Some farmers use a grafting system as described by Kurniaatmadja (1969). Cuttings of $M$. esculenta and $M$. glaziovii are planted separately. About 45 days after planting young shoots of $M$. glaziovii are grafted on young shoots of $M$. esculenta. The system is very laborious and not often used. Kurniaatmadja (1969) has called this way of working the 'Kurur' system but, in fact, it should be considered as a modification of the Mukibat system.

Another way of practising the Mukibat system is the 'Satrawi' modification (Anon. 1973) developed by a farmer, Satrawi. In this modification the scion of $M$. glaziovii is connected with 3 or 5 stocks of $M$. esculenta, each $75 \mathrm{~cm}$ long, This grafting system is quite laborious and easily fails. But yielding capacity is said to be much higher than that of the normal Mukibat system, especially in shady places (Fig. 3).

Budding. In a few cases planting material is prepared by budding, both by patchbudding (Taufik Budiman, 1972) and by T-budding (Endjo Tirtasuganda, 1962). In fact Mukibat himself used the budding system in his first experiments. On a suitable stem of a $M$. esculenta plant several $M$. glaziovii buds can be inserted about $30 \mathrm{~cm}$ apart. After 2 weeks, if budding succeeds, the stem parts can be cut and planted. But cutting of the grafted stem parts can be postponed if necessary. Because application of the budding system is more difficult and laborious and because the percentage of success is often very low, budding is only used in a few cases. Some farmers assert that with budding production of tuberous roots is higher than with grafting. An advantage of the budding system is that the resulting plants are more resistant to strong 


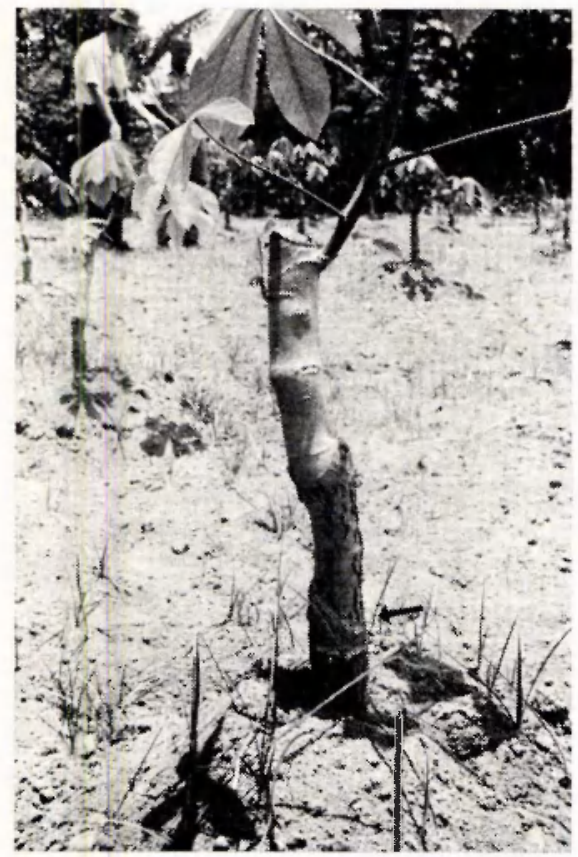

Fig. 4. One-month old plant in the second planting season. The arrow indicates the original connection.

winds than plants derived from grafting, which is important in windy areas.

A modification of the budding method is the 'Djajadi' system (Endjo Tirtasuganda, 1962). The budded cuttings are put in vertical position on a moist soil until roots start growing. To promote a better root system, before planting a circular incision is made in the bark of the cuttings $1 \mathrm{~cm}$ above the young roots.

Replanting of curtings. After the first yield the grafted or budded cuttings can be replanted once or even twice, on condition that the stock is long enough. Fig. 4 presents an example of such a plant. At the top end the $M$. glaziovii stems are cut about $15 \mathrm{~cm}$ above the original connection. At the bottom end, the $M$. esculenta stock is shortened by about $5 \mathrm{~cm}$.

It is not yet quite clear in what season the best yield and root quality is obtained. In the second and third season plants are growing more vigourously, but tuberous roots are said quickly to become woody in the third season.

\subsection{Planting method}

In most cases a big hole is made before planting. The diameter varies from $0.5-1.5 \mathrm{~m}$ and the depth from $0.1-1 \mathrm{~m}$, depending on soil conditions and local customs. Usually a size of $1 \times 1 \times 0.5 \mathrm{~m}$ is recommended.

An amount of organic matter, varying from 5 to $25 \mathrm{~kg}$ (on moist base), is put in every hole and mixed with the soil, after which the holes are filled with soil and hilled up.

One grafted or budded cutting is planted on each hill, in a vertical position. Planting 
depth is about $10 \mathrm{~cm}$. It is assumed that the shallower the cutting is planted, the better will be the yield.

To plant not deeper than $5 \mathrm{~cm}$ (Subur Djatiwalujo, 1973), sometimes the cutting is lengthened by putting a bamboo stick in the pith of the bottom end.

Plant spacing varies from $1.5-3 \mathrm{~m} \times 1.5-3 \mathrm{~m}$, thus from about 2 to $9 \mathrm{~m}^{2}$ per plant. Usually a spacing of $2 \times 2 \mathrm{~m}$ is used.

Often the holes are made some months before planting. All kinds of organic matter such as leaves, banana leaf stalks, kitchen waste etc. and also ash are put in the holes, which are then covered with soil. This method represents an efficient way of making use of household and farmyard waste and promotes clean farmyards.

The hole system with the use of organic matter was already practised for ordinary cassava growing before Mukibat started his experiments. He adopted it for his system (Koesmadi, 1958). In East-Java the hole system is known as 'Bajang' system and probably originated from the village Bajang in the Blitar regency.

The effectiveness of the Mukibat system is mostly said to be the result of the combination of the 'Bajang' system and the Mukibat grafting system. But in some regions, especially in the Pacitan district, instead of digging labour intensive holes, farmers only make very shallow holes (about $10 \mathrm{~cm}$ ), mix organic matter with the soil and make small hills or ridges on which the cuttings are planted (Purwohadi Wijoyo, 1973). Especially on less permeable soil the hole system is said to be unfavourable because of water-logging.

Although in most regions the Mukibat system is used on the farmyard only, in the Pacitan district the system is more and more practised on dry land outside the farmyard, mostly without making holes, and sometimes with only a very limited quantity of organic matter.

It is not yet exactly known what is the sole effect of making holes. According to Taufik Budiman (1972) yield is positively correlated with the size of the holes. But in the Pacitan district high yields are said to be obtained without using the hole system (Purwohadi Wijoyo, 1973). Also in the 'Kurur' modification (Kurniaatmadja, 1969), no holes are made.

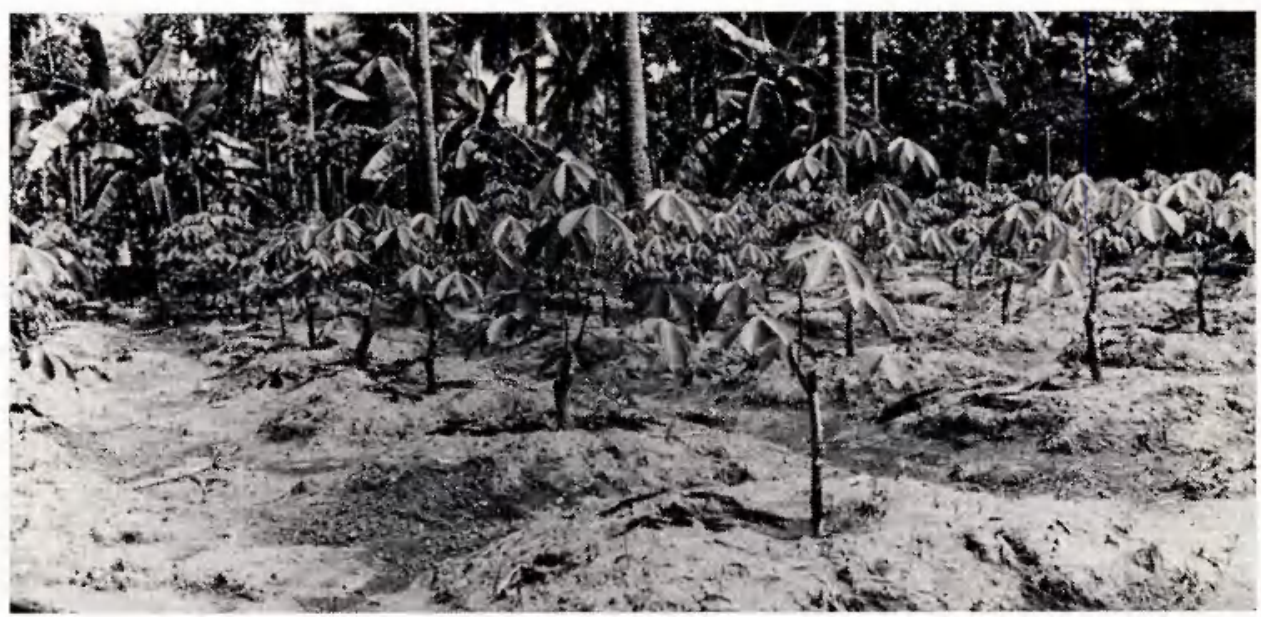

Fig. 5. Young Mukibat plants on a farmer's backyard. 
Often efforts are made to increase the number of roots per plant in order to promote a higher yield. More roots can be obtained in the following ways:

- the bottom end of the cutting is cut slantingly;

- a circular incision is made in the peel of the bottom end of the cutting (Endjo Tirlasuganda, 1962);

- the bottom end of the cutting is split longitudionally by sawing in the centre up to about $10 \mathrm{~cm}$ (Subur Djatiwalujo, 1973);

- the 'Satrawi' modification of the Mukibat system (Section 2.1.).

\subsection{Planting time}

Planting mostly takes place in the beginning of the rainy season, thus for East-Java in the period from September to November. This generally fits well into the farmers planting scheme and coincides with planting time of normal cassava. Often planting material is already prepared at the end of the dry season. Nevertheless planting can also be carried out in other periods of the year provided that water is sufficient. But, as mentioned before, grafting during the rainy season is less successful than in the dry season.

\subsection{Intercropping}

Mukibat cassava, like normal cassava, is often planted in some kind of intercropping or mixed cropping system, with different kinds of food crops, such as maize, upland rice, soybeans and vegetables. It should be noted, however, that for intercropping with smaller plants Mukibat cassava is less suitable than normal cassava, because of the heavy shade caused by the very dense leaf canopy of the Mukibat plants. On the other hand the Mukibat cassava plant is said still to produce a reasonable quantity of tuberous roots in shady places, where normal cassava does not produce anymore (Purwohadi Wijoyo, 1973). As reported earlier (Section 2.1.) in shady places the 'Satrawi' modification of the Mukibat system, in which 3 or more stocks are connected with one scion, gives a higher yield than the normal Mukibat system (Anon., 1973).

\subsection{Manuring}

The pattern of manuring varies considerably from one region to another and from one farmer to another. In most cases organic matter is used. The quantity given also varies and may be as much as $25 \mathrm{~kg}$ of moist matter per plant. Also the kind and nature of the organic matter is very different. Farmers use farmyard and household waste, farm manure, rice straw, etc., either processed to compost or not. Decomposed material is preferred to fresh plant material. Subur Djatiwalujo (1973) reports that some farmers do not use farmyard manure, because this could promote the development of pests and diseases.

The organic matter is mostly given once, at the moment of planting or before, but in some cases another quantity is added during the growing period, about 4 to 5 months after planting. Kurniaatmadja (1969) recommends manuring with $3-5 \mathrm{~kg}$ of ash at the moment of planting and, in addition, with green manure during growth. For this purpose two weeks after planting Crotalaria is sown between the plants. Later on the Crotalaria is cut, put around the cassava plants and covered with soil.

The use of fertilizers is still very limited. Some advanced farmers give a small amount 


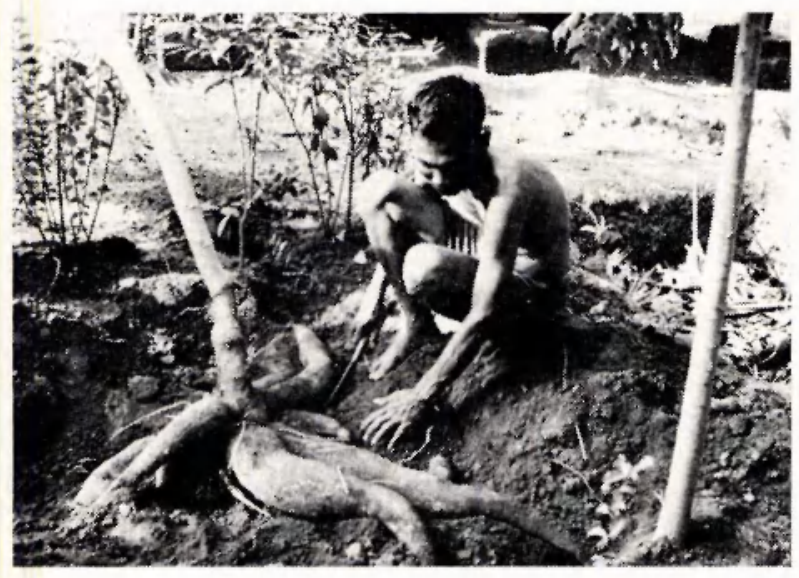

Fig. 6. Eleven-month old Mukibat plant. Yield: $32 \mathrm{~kg}$ of tuberous roots.

of urea, once or twice during the growing period. Purwohadi Wijoyo (1973) reports that in the Madiun region the use of urea is quite common.

\subsection{Plant care}

Plant care generally comprises weeding once or twice, sometimes combined with hilling up. Some farmers protect their plants against winds by supporting them with bamboo. Control of pests and diseases in most cases is not necessary, the Mukibat cassava, like normal cassava, being relatively rarely attacked by pests and diseases. In general plants are not irrigated. Only in some cases, when farmers already plant before the beginning of the rainy season, initial irrigation is needed.

\subsection{Growing period and yield}

The growing period for the Mukibat system may vary from 8 to 18 months, depending on variety, local customs and the need for food. Mostly harvest takes place about 10 months after planting (Fig. 6). The tuberous roots of the Mukibat plants are not only thicker but also longer, and probably more numerous than those of normal plants.

If plants are too young it is a pity to harvest them because they are still growing quickly. But if plants are more than one year old root quality is said to decrease. The roots become woody and the taste deteriorates. Moreover, many varieties cannot stand the excess of water during the next rainy season. In the Pacitan district, however, according to Purwohadi Wijoyo (1973) farmers found that a suitable balance between high yield and root quality is reached if harvesting takes place after 18 months.

In some cases, because of the large quantity of tuberous roots per plant, the roots are harvested gradually, one by one.

Table 1 presents data from different authors about growing period, spacing and yield obtained. Reported yields were obtained from small plots only and were expressed in $\mathrm{kg}$ per plant. To facilitate comparison we have converted the figures to units of tonnes per ha per year, by linear extrapolation. Yields of tuberous roots given by the seven authors cited amount to 96 tonnes per ha per year on average. Although the yields reported by the various authors are relatively quite uniform it must be admitted 
Table 1. Yield of tuberous roots obtained by the Mukibat system, for different growing periods and plant spacing, as reported by seven authors.

\begin{tabular}{|c|c|c|c|c|c|c|c|}
\hline \multirow[t]{3}{*}{ Authors } & \multirow{3}{*}{$\begin{array}{l}\text { Growing } \\
\text { period } \\
\text { (months) }\end{array}$} & \multirow{3}{*}{$\begin{array}{l}\text { Plant } \\
\text { spacing } \\
(\mathrm{m} \times \mathrm{m})\end{array}$} & \multirow{3}{*}{$\begin{array}{l}\text { Area/plant } \\
\left(\mathrm{m}^{2}\right)\end{array}$} & \multicolumn{4}{|c|}{ Yield of tuberous roots (fresh weight) } \\
\hline & & & & \multirow{2}{*}{$\begin{array}{l}\text { reported } \\
\mathrm{kg} / \\
\text { plant }\end{array}$} & \multicolumn{3}{|c|}{ calculated } \\
\hline & & & & & $\begin{array}{l}\text { tonnes/ } \\
\text { ha }\end{array}$ & $\begin{array}{l}\text { tonnes/ } \\
\text { (ha.year) }\end{array}$ & $\begin{array}{l}\text { average } \\
\text { tonnes/ } \\
\text { (ha.year) }\end{array}$ \\
\hline Koesmadi (1958) & $\begin{array}{r}13 \\
10 \\
10 \\
9 \\
11\end{array}$ & $\begin{array}{l}? \\
? \\
? \\
? \\
?\end{array}$ & $\begin{array}{l}9 * \\
9^{*} \\
9^{*} \\
9^{*} \\
9^{*}\end{array}$ & $\begin{array}{r}58 \\
54 \\
61 \\
93 \\
123\end{array}$ & $\begin{array}{r}64 \\
60 \\
68 \\
100 \\
137\end{array}$ & $\begin{array}{r}59 \\
70 \\
75 \\
133 \\
150\end{array}$ & 97 \\
\hline Kurniaatmadja (1969) & $\begin{array}{l}12-13 \\
12-13 \\
12-13\end{array}$ & $\begin{aligned} 2 & \times 2 \\
2.5 & \times 2.5 \\
3 & \times 3\end{aligned}$ & $\begin{array}{l}4 \\
6.25 \\
9\end{array}$ & $\begin{array}{l}35 \\
50 \\
75\end{array}$ & $\begin{array}{l}88 \\
80 \\
83\end{array}$ & $\begin{array}{l}84 \\
77 \\
80\end{array}$ & 81 \\
\hline Taufik Budiman (1972) & $12-15$ & $2.5 \times 3$ & 7.5 & 100 & 133 & 106 & 106 \\
\hline Anonymus (1973) & 12 & $?$ & $9 *$ & 104 & 115 & 115 & 115 \\
\hline Purwohadi Wijoyo (1973) & $\begin{array}{l}8-9 \\
18\end{array}$ & $\begin{array}{l}1.5 \times 2 \\
?\end{array}$ & $\begin{array}{l}3 \\
6^{*}\end{array}$ & $\begin{array}{l}20-25 \\
50-100\end{array}$ & $\begin{array}{r}75 \\
125\end{array}$ & $\begin{array}{r}100 \\
83\end{array}$ & 91 \\
\hline Subur Djatiwalujo (1973) & $10-12$ & $2 \times 2$ & 4 & $25-30$ & 69 & 75 & 75 \\
\hline Syekhfani (1973) & $8-9$ & $2 \times 2$ & 4 & $25-40$ & 81 & 108 & 108 \\
\hline
\end{tabular}

* Estimated maximum.

that, as the data have not been obtained by purely scientific research, some figures may be overestimated because of the tendency of producers to report only the highest yield figures.

To produce very big tuberous roots, as often used for exhibition purposes, the growing period may be extended to 2 years. In such cases a very high production per plant can be obtained. The highest yield reported to the authors is $195 \mathrm{~kg}$ of roots for a plant of 18 months, shown at an exhibition in the district of Tulungagung. Roots of

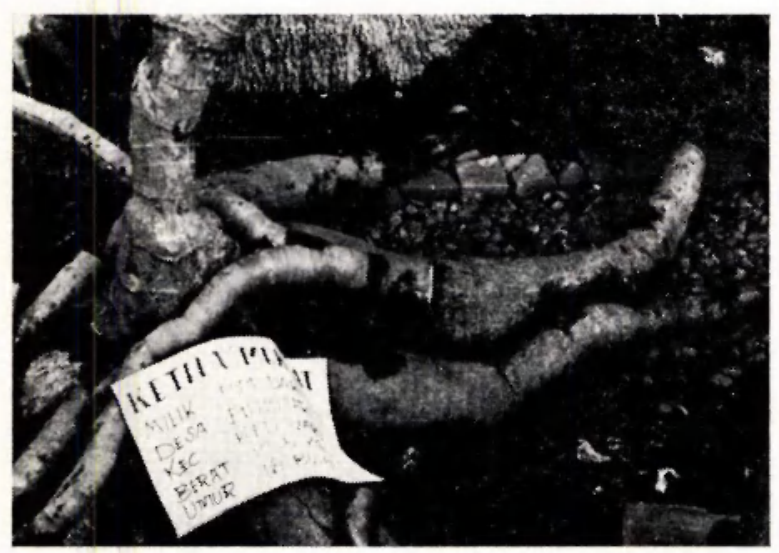

Neth. J.agric. Sci. 22 (1974)
Fig. 7. Eighteen-month old Mukibat plant for exhibition purpose. Yield: $195 \mathrm{~kg}$ of tuberous roots. Courtesy: Dinas Pertanian Rakyat, Kabupaten Tulungagung. 
this plant were as thick as a human leg (Fig. 7).

Tuberous roots from the Mukibat plants are generally reported to have a higher water content than roots produced by the normal system, but no exact data are available as yet.

\subsection{Root quality}

In some regions the taste of tuberous roots of the Mukibat cassava is considered inferior to that of normal cassava and this may be one of the reasons that could hinder a rapid expansion of the system (Sumarto, 1973; Syekhfani, 1973; Purwohadi Wijoyo, 1973). But in the regions where the system already has been adopted no complaints about taste are reported. It is assumed, however, that, to obtain a good quality, harvesting must take place between certain limits of plant age.

It seems likely that some adaptation to taste is necessary as is the case with most new products.

No information is available about influence of the Mukibat growing system on the cyanogenic glucosides of the tuberous roots.

\section{Discussion}

\subsection{Practical significance of the system}

When the Mukibat system is considered critically, one of the first questions to be posed is how much higher will be the production obtained by the new system, in comparison to the conventional cassava production system. In fact the authors could not find any data of comparative studies on this question and also from farmers practising the system no clear data could be obtained, except that uniformly is stated that the Mukibat system is outyielding the normal system.

As comparative studies are lacking only yields obtained by both systems separately could be compared. But such a comparison would not be valid because reported Mukibat yields have been obtained from small plots only, under different and much more favourable cultural conditions than those usual for ordinary cassava growing.

Nevertheless there are some strong indications confirming the farmers' assertion that the Mukibat system is outyielding the usual system:

- Yields of individual Mukibat plants are extremely high and have never been reached by the normal system.

- Comparable grafting experiments in South-America (Mogilner et al., 1969), which have been executed more recently and probably independently from that of Mukibat, indicated that grafting of $M$. flabellifolia on $M$. esculenta gave a more than double yield of tuberous roots, as compared to that of the $M$. esculenta control (average increase $135 \%$ ).

-- The rapid expansion of the Mukibat system amongst Indonisian farmers, even leading to its superseding the usual system, probably is the strongest indication of the validity of the new system, at least for backyard production.

We roughly estimate that, under comparable ecological conditions, yields obtained by the Mukibat system can at least double those obtained by the usual system. Average production of normal cassava in East-Java amounts to 7 tonnes per ha per season of about 9 months (Anon., 1971).

However, even if it is assumed that the Mukibat system is largely outyielding the 
normal system and that its importance for backyard cassava production in Indonesia has already been proven, it still remains to be seen if the system can lead to an increase of farmers' income in other parts of the tropics. Therefore, the economic feasibility of the system should be considered for each cassava production region separately.

Another question to be posed is whether the system could be applied for large-scale, possibly mechanized, production. The present Indonesian system is a very labourintensive one. Cultivation practises could possibly be simplified, for instance by omitting the digging of big holes, as, in fact, is already done in some regions.

It is evident that many questions about the agronomy and the practical significance of the Mukibat system still have to be answered and that further research is needed.

\subsection{Comparison of Mukibat yield to estimated potential cassava yield}

The highest reported yield obtained by normal cassava growing amounts to 71 tonnes of tuberous roots per ha per year (de Vries et al., 1967). But estimated potential cassava yields are higher still. De Vries et al. (1967) estimated the net potential dry matter production of root and tuber crops, under average light conditions, at $550 \times 10^{3} \mathrm{cal}$ ha-1 day-1, which equals $137.5 \mathrm{~kg}$ of carbohydrate equivalents or about 50 tonnes of dry matter per ha per year. Assuming that in cassava potentially $60 \%$ of the total dry matter produced can be stored in the tuberous roots, the potential root production will be 30 tonnes per ha per year, corresponding to about 90 tonnes of fresh tuberous roots per ha per year.

From Table 1 it may be concluded that in the Mukibat system a yield of 71 tonnes of tuberous roots per ha per year is quite feasible. The potential yield of cassava, as estimated by de Vries et al. (1967) can even be surpassed, possibly because of the higher light intensity in the area.

\subsection{Possible explanations of the higher yields}

Besides the practical considerations on the Mukibat system also the physiological background is of interest and of importance. It is clear that in the Mukibat plants the sink capacity in the tuberous roots is higher than in normal cassava plants. One of the causes of the increase of the sink capacity could be a higher supply of assimilates to the tuberous roots. Other factors could be influencing the sink capacity independently from the supply of assimilates.

A higher supply of assimilates, leading to an increase of sink activity, could be caused by a higher leaf area index (LAI) of the Mukibat plants. According to our estimate, during the growing period the LAI of Mukibat plants on average is higher than that of normal plants. Whilst at a certain age and in dry conditions there is a stagnation in leaf formation in the $M$. esculenta canopy, this stagnation seems to be much less in the $M$. glaziovii canopy. This may be so because $M$. glaziovii is a perennial, and because the planting holes promote a bigger and deeper rooting system. But a higher LAI of cassava plants does not automatically cause a higher sink activity (Williams, 1972); in the case of grafting of $M$. flabellifolia on $M$. esculenta, Mogilner et al. (1969) stated that $M$. esculenta had a greater leaf area and higher photosynthetic intensity than the grafted plant which, however, transferred a greater quantity of photosynthetic substances to the storage roots'.

According to Williams (1972) there is a relation between the sink activity and the rate of assimilation in this sense that it seems likely that higher rates of assimilation 
and the greater development of total dry matter as well as of tubers, is at least partly brought about by a higher demand for assimilates by the developing storage roots'.

As to factors causing a higher sink capacity or activity independently from the supply of assimilates, hormonal factors could be thought of. According to a review of Williams (1974) this possibility seems likely in the case of potato tuberization. Moreover, Bolhuis' (1966) results on influence of day-length on tuberization can only be explained by a hormonal system. Thus, in Mukibat plants hormones produced by the $M$. glaziovii canopy might increase the sink activity already present of the $M$. esculenta roots. As mentioned earlier, the sink capacity of $M$. glaziovii itself is extremely low.

Finally, a possible mutual influence of scion and stock could be contributing to the high sink activity of the Mukibat plants.

\section{Acknowledgments}

The authors thank the Direction of the Netherlands University Foundation For International Cooperation (NUFFIC) which supplied funds to start research on the Mukibat system, and the Board of the International Development Research Centre (IDRC) which provided funds for further research activities in the coming years.

The authors are indebted to Dean Ir Baskoro Winarno for his co-operation and stimulation, to Dr M. Flach for his valuable comments and to Mrs A. G. J. Flachte Velde for correction of the English text.

\section{References}

Anonymus, 1971. Buku rata-rata 10 tahun $1960 \mathrm{~s} / \mathrm{d}$ 1969. Panen, produksi dan areal tanaman dari tanaman bahan makanan utama di Djawa-Timur. Issued by Dinas Pertanian Rakyat Propinsi Jawa Timur, Surabaya.

Anonymus, 1973. Ketela pohon 'Satrawi'. Issued by Dinas Pertanian Rakyat Kabupaten Malang.

Bolhuis, G. G., 1966. Influence of the length of the illumination period on root formation in cassava. Neth. J.agric. Sci. 14: 251-254.

Endjo Tirtasuganda, 1962. Menanam ketela pohon system Djajadi. Madjalah Pertanian 5: 124.

Koesmadi, R., 1958. Ketela Pohon. Usaha mempertinggi ketela pohon dengan model Mukibat. 8 pp. Workshop Pertanian, Djuni 1958. Issued by Dinas Pertanian Rakyat Propinsi Jawa Timur, Surabaya.

Kurniaatmadja, 1969. Menanam ketela pohon setjara berentjana menurut sistim Kurur. Madjalah Pertanian 17 (4/5): 10-27.

Mogilner, I., J. D. Portuguez A., A. D. Gotuzzo \& J. A. Acosta, 1969. Influence of Manihot flabellifolia as a scion on the formation of storage roots in $M$. esculenta as a stock. Field Crops Abstr. 22: 71 (No 538). (Original: Bonplandia (Argentina) 2 (1967) (10): 137-142.)

Purwohadi Wijoyo, 1973. Laporan survey pendahuluan tentang cassava di kabupaten Madiun, Pacitan dan Ponorogo. April 1973. Internal Report, Faculty of Agriculture, Brawijaya University, Malang. $20 \mathrm{pp}$.

Subur Djatiwalujo, 1973. Laporan tentang hasil survey pendahuluan ketela pohon di kabupaten Lumajang, Malang dan Blitar. April 1973. Internal Report, Faculty of Agriculture, Brawijaya University, Malang. $7 \mathrm{pp}$.

Sumarto, C. M., 1973. Laporan survey pendahuluan ketela pohon di Madura. April 1973. Internal Report, Faculty of Agriculture, Brawijaya University, Malang. 9 pp.

Syekhfani, Ms., 1973. Ketela pohon di Kabupaten Lamongan dan Tuban. April 1973. Internal Report, Faculty of Agriculture, Brawijaya University, Malang. $24 \mathrm{pp}$

Taufik Budiman, 1972. Sebatang singkong dapat berumbi satu kwintal. Intisari 8 (No 102): 121-124.

Vries, C. A. de, J. D. Ferwerda \& M. Flach, 1967. Choice of food crops in relation to actual and potential production in the tropics. Neth. J. agric. Sci. 15 (1967): 241-248.

Williams, C. N., 1972. Growth and productivity of tapioca (Manihot utilissima). 111. Crop ratio, spacing and yield. Expl Agric. 8: 15-23.

Williams, C. N., 1974. Growth and productivity of tapioca (Manihot utilissima). IV. Development and yield of tubers. Expl Agric. 10: 9-16. 